\title{
Solid desiccants from natural and modified bentonites
}

\section{(Dessecantes sólidos de bentonitas naturais e modificadas)}

\author{
N. Castrillo ${ }^{1,2 *}$, A. Mercado ${ }^{2,3}$, C. Volzone ${ }^{4}$ \\ ${ }^{1}$ Universidad Nacional de Salta, Iniqui-Conicet, CP 4400, Salta, Argentina \\ ${ }^{2}$ Universidad Nacional de Salta, Ciunsa, Salta, Argentina \\ ${ }^{3}$ Universidad Nacional de Salta, Facultad de Ciencias Exactas, Salta, Argentina \\ ${ }^{4}$ CETMIC (CCT-CONICET La Plata, CIC-PBA), M.B. Gonnet, Buenos Aires, Argentina
}

\begin{abstract}
The aim of the present work was to study Argentinean natural clays with different modifications and their use as desiccants. To this end, bentonite clays collected from different regions were characterized and modified by heat treatment and calcium addition, and the desiccant capacity, in the form of powder and pellets, was studied. In addition, the hydration degree reversibility of these materials was estimated. The mineralogical and structural characterization was performed by X-ray diffraction, Fourier-transform infrared spectroscopy, differential thermal analysis, and thermogravimetric analysis. The textural characterization was performed by adsorption-desorption of $\mathrm{N}_{2}$, chemical composition by X-ray fluorescence and cation exchange capacity. The water adsorption was determined at $25{ }^{\circ} \mathrm{C}$ between $11-98 \%$ relative humidity. The results indicated that the desiccant power has a close relationship with the degree of clay purity, drying of the sample and the method of calcium incorporation.
\end{abstract}

Keywords: adsorption, bentonites, desiccants, characterization.

Resumo

O objetivo do presente trabalho foi estudar argilas naturais argentinas com diferentes modificações e seu uso como dessecantes. Para tanto, as argilas bentoníticas coletadas de diferentes regiões foram caracterizadas e modificadas por tratamento térmico e adição de cálcio, e a capacidade dessecante, em forma de pó e pelotas, foi estudada. Além disso, a reversibilidade do grau de hidratação desses materiais foi estimada. A caracterização mineralógica e estrutural foi realizada por difração de raios $X$, espectroscopia no infravermelho com transformada de Fourier, análise térmica diferencial e análise termogravimétrica. A caracterização textural foi realizada por adsorção-dessorção de $N_{2}$, composição química por fluorescência de raios X e capacidade de troca catiônica. A adsorção de água foi determinada a $25{ }^{\circ} \mathrm{C}$ entre $11-98 \%$ de umidade relativa. Os resultados indicaram que o poder dessecante tem relação estreita com o grau de pureza da argila, a secagem da amostra e o método de incorporação de cálcio.

Palavras-chave: adsorção, bentonitas, dessecantes, caracterização.

\section{INTRODUCTION}

Desiccants are agents that exhibit a strong affinity to moisture (water vapor) which adsorb from the atmosphere. Dehumidification contributes to avoiding problems such as corrosion, condensation, odors, mold, etc. Industries that use desiccants include packaging of electronic, pharmaceutical and industrial components [1]. The most commonly used are silica gel, molecular sieves, clays, calcium chloride and activated carbon [2]. The high adsorption of water and its regeneration capacity has promoted the mass application of these desiccants through research and development [3]. During regeneration, a desiccant releases water vapor while heat is transferred to it, being once again prepared for adsorption. However, after the adsorption-regeneration cycles, it loses effectiveness due to thermal and mechanical degradation and contamination [4].

Clay is a cheap, non-corrosive and effective desiccant

*ncastrillo@unsa.edu.ar within a normal temperature range and relative humidity (RH). After adsorption, it remains dry and solid, with no apparent change in texture. In addition, its production as a desiccant has a low environmental impact. Clays are the product of the disintegration of igneous rocks, over long periods of time. They are mixtures of mineral species, according to the composition of the matrix rock and the weathering process [5]. They have impurities generally of quartz, gypsum and feldspar. For example, a bentonite is a clay with a high percentage of smectite clay mineral and low impurity content. In Argentina, the extraction of bentonites is located in Río Negro, La Pampa, San Juan, Neuquén and Mendoza provinces [6]. Today commercial clays are among the most important mineral resources, $90 \%$ is for building materials and aggregates [7]. The remaining $10 \%$ is consigned to other industries, including paints, adsorbents [8], bleaches [9], chemical and pharmaceutical products [10].

The most striking structural feature of smectite is that different molecules can penetrate between the lamellas causing an expansion of the network. In this sense, water 
adsorption in the interlayer is governed by the nature and loading of the saturation cation, as well as by the value and location of the laminar charge [8, 11-13]. At a given RH, the interlayer cations are hydrated to form coordination complexes with defined interlamellar spacing [(001) reflexion values from XRD analysis]. As RH increases, unfilled spaces between the hydrated cations are occupied with water molecules, being linked to one another by hydrogen bonds. Thus, exchange cations contribute strongly to the energy of interlayer hydration [14]. When the bentonite is subjected to heat treatments or mixed with suitable chemical additives, effective drying materials are obtained by virtue of the removal of water molecules at adsorbent sites and the establishment of more hydrophilic sites. In this sense, the RH and temperature play an important role, together with the structure and mineralogy [11-13, 15]. Desiccants containing Ca have been developed by studying the adsorption capacity as a function of RH [16].

The purpose of the present work was to characterize two Argentinean bentonites. The study of water adsorption in its natural and purified conditions, as well as after modifications such as thermal treatment and aggregation of $\mathrm{Ca}$ through different methods, was deepened, with a subsequent comparative study of them. Possible mechanisms, as well as the energies involved in the adsorption processes, were established. Bentonites were pelletized to adapt them to real operating conditions. A comparative study of the adsorption efficiency with respect to the powder samples and the regenerated materials was carried out.

\section{MATERIALS AND METHODS}

In order to analyze the influence of the structure and mineralogical composition of bentonites in their behavior as a desiccant, clays of different geological origin were selected: an ocher bentonite from Río Negro called BR and a white bentonite from San Juan called BG. The samples were homogenized and reduced to a particle size $<100$ mesh. The purified clay fraction $(<2 \mu \mathrm{m})$ was obtained by sedimentation, according to Stokes's law. The samples were named BRp and BGp, respectively.

Characterization methods: X-ray diffraction (XRD) patterns were obtained using a Philips PW 3710, $3 \mathrm{~kW}$, with $\mathrm{CuK} \alpha$ radiation, $45 \mathrm{kV}, 20 \mathrm{~mA}$, and sweep range $2 \theta$ from 3 to $70^{\circ}$. Total sample diffractograms were obtained. For the mineralogical identification, the powder diffraction file database was used. Fourie transform infrared (FTIR) studies were performed on a Spectrum GX Perkin Elmer. Absorption spectra were obtained in the range $4000-400 \mathrm{~cm}^{-1}$. The predried samples were prepared in $\mathrm{KBr}$-supported pellets. Thermal analysis (DTA-TG - differential thermal analysisthermogravimetry) were performed simultaneously on a STA 409 Netsch equipment. The heating rate was $10{ }^{\circ} \mathrm{C} / \mathrm{min}$ in air atmosphere up to $1000{ }^{\circ} \mathrm{C}$. The textural characterization was performed from the adsorption isotherms of $\mathrm{N}_{2}$ at 77 $\mathrm{K}$ in a Micromeritics ASAP 2020 analyzer. Each sample was degassed at $150{ }^{\circ} \mathrm{C}$ under vacuum for $10 \mathrm{~h}$. Apparent specific surface areas $\left(\mathrm{S}_{\mathrm{BET}}\right)$ were obtained by applying the BET method, using data in the relative pressure ranges $\left(\mathrm{P} / \mathrm{P}_{0}\right)$ where linearity conditions and method considerations were satisfied [17]. The chemical composition was determined by $\mathrm{X}$-ray fluorescence. A wavelength-dispersive spectrometer with $\mathrm{Rh}$ tube $3 \mathrm{~kW}$ was used. It was worked at $50 \mathrm{kV}$ and $40 \mathrm{~mA}$. Samples were prepared by melting with $\mathrm{Li}$ tetraborate at $950{ }^{\circ} \mathrm{C}$ at a sample:flux ratio of $1: 10$. The loss of ignition (LOI) at $1000{ }^{\circ} \mathrm{C}$ was also determined. To determine cation exchange capacity (CEC), each sample was saturated with $0.5 \mathrm{M} \mathrm{NH}_{4}\left(\mathrm{CH}_{3} \mathrm{COO}\right)$, allowed to stir and centrifuged. It was then washed with methanol. Then the sample was dried and disintegrated in $\mathrm{H}_{2} \mathrm{SO}_{4}(18 \mathrm{M})$ to perform $\mathrm{NH}_{4}^{+}$determination by the Kjeldhal method [18] and later the CEC was calculated (meq/100 g clay).

Sample preparation. Thermal treatment: the samples were treated at 100,300 and $500{ }^{\circ} \mathrm{C}$ at a heating rate of $12{ }^{\circ} \mathrm{C} / \mathrm{min}$ and maintaining the programmed temperature for $180 \mathrm{~min}$. They were identified as B-100, B-300 and B-500. Calcium treatments: materials were referred with the bentonite name, followed by aggregate $\mathrm{Ca}$ percentage in weight and then the incorporation via. Thus, BR-1m represented the material prepared with bentonite $\mathrm{BR}$ to which $1 \% \mathrm{Ca}$ was added by mechanical via, using letter $\mathrm{i}$ to represent the exchange via. $\mathrm{Ca}$ addition by ion exchange: the percentages ofCa added, between 1 and $4 \%$, were related to the different CEC percentage of the natural bentonites (between 50 and $250 \%$ CEC). Attained the CEC equivalent (with a content of $2 \%$ in $\mathrm{Ca}$ ), the incorporated amount remained constant, so the samples chosen for further studies were the B-2i. Ca aggregated by mechanic treatment: different amounts of $\mathrm{CaCl}_{2} \cdot 2 \mathrm{H}_{2} \mathrm{O}$ in Ca percentages between 1 and $13 \%$ were added to the clay. The mixture was made by grinding and subsequently $<100$ mesh particle size was ensured.

Desiccant capacity of samples: desiccant capacity tests were carried out at $25{ }^{\circ} \mathrm{C}$ in closed environments between $11-98 \%$ RH. The indicated RH values were obtained with saturated salt solutions: $11 \%$ with $\mathrm{LiCl}, 33 \%$ with $\mathrm{MgCl}_{2}$, $56 \%$ with $\mathrm{Mg}\left(\mathrm{NO}_{3}\right), 75 \%$ with $\mathrm{NaCl}$, and $98 \%$ with $\mathrm{K}_{2} \mathrm{SO}_{4}$. Subsequently, a known amount of dry sample was placed in the desiccator at an appropriate $\mathrm{RH}$ and periodic weighing was carried out until obtaining constant mass [19].

Kinetic study at $98 \% \mathrm{RH}$ and $25{ }^{\circ} \mathrm{C}$ - hydration energy: the adsorption processes were studied applying the pseudosecond-order kinetic model [20] to then predict characteristic parameters and some degree of chemical interaction. Thus, the hydration energies associated with the desiccant capacity were also calculated by the BET method $[17,21]$.

Preparation of pellets: dry bentonite powder, was poured onto a granulator disk with rotary motion. Water was added in fine drops to obtain spherical, compacted and moist granules. Subsequently, the pellets were dried and sieved, preserving those retained between 4-6 mesh (3.4-4.8 mm). This fraction was treated at $150{ }^{\circ} \mathrm{C}$ during $3 \mathrm{~h}$. The pellets were identified as $\mathrm{B}^{\mathrm{P}}-150$ and analyzed by FTIR.

Thermal regeneration: the studies of regeneration of the samples, until reaching a constant mass, were performed 
after the first cycle of adsorption at $98 \% \mathrm{RH}$ and $25{ }^{\circ} \mathrm{C}$. Subsequently, five successive adsorption-regeneration cycles were performed under the same conditions previously described. In order to compare the results, the equilibrium times of the first cycle (Table I) were important to conclude the subsequent cycles.

Table I - Equilibrium times of the first cycle. [Tabela I - Tempos de equilíbrio do primeiro ciclo.]

\begin{tabular}{cccc}
\hline \multirow{2}{*}{ Sample } & Adsorption at $98 \%$ & \multicolumn{2}{c}{ Regeneration (h) } \\
& $\mathrm{RH}$ and $25^{\circ} \mathrm{C}$ (day) & $100{ }^{\circ} \mathrm{C}$ & $150{ }^{\circ} \mathrm{C}$ \\
\hline B and B-2-i & 5 & 3 & - \\
B-10-m & 7 & 3 & - \\
$\mathrm{B}^{\mathrm{P}}-150$ & 21 & - & 3 \\
\hline
\end{tabular}

\section{RESULTS AND DISCUSSION}

\section{Characterization}

Natural and purified bentonites: Fig. 1 shows the XRD results of the bentonites before and after purified conditions. $\mathrm{BR}$ bentonite presented the most intense montmorillonite
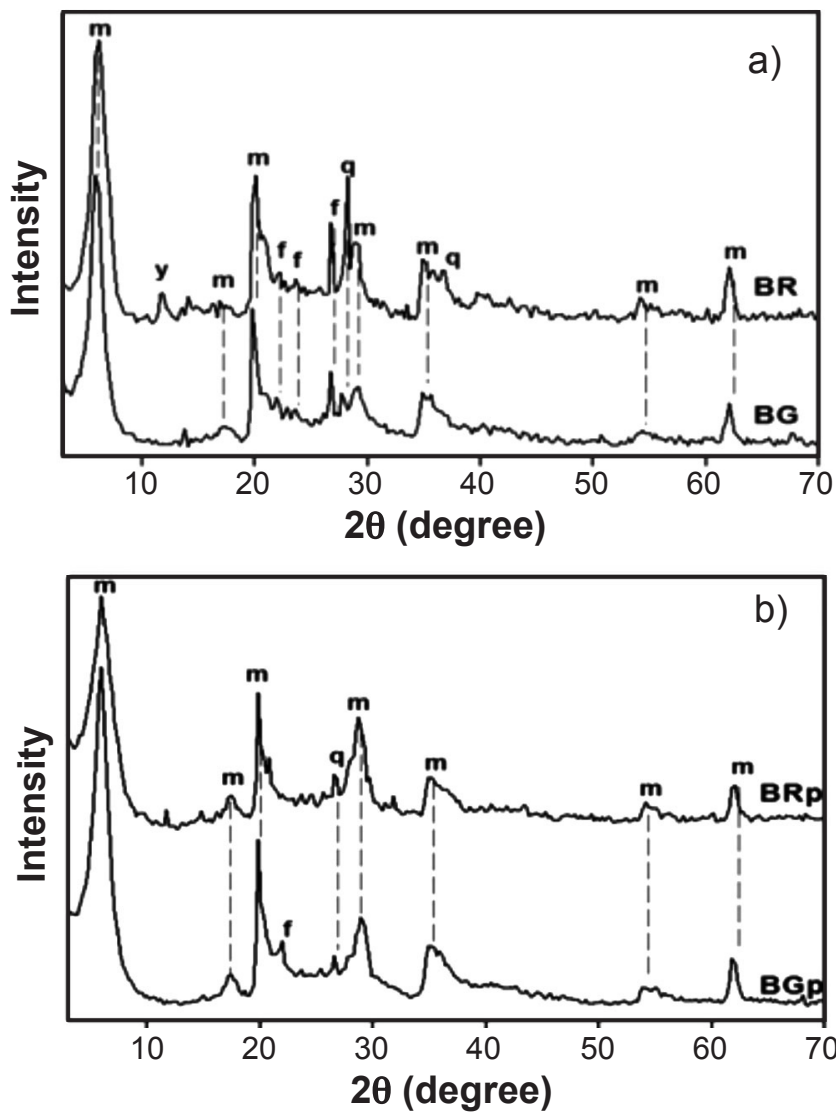

Figure 1: XRD patterns of natural bentonite (a), and purified bentonite (b); m - montmorillonite; q - quartz; f - feldspar; y gypsum.

[Figura 1: Difratogramas de raios $X$ de bentonita natural (a) e bentonita purificada $(b) ; m$ - montmorilonita; $q$ - quartzo; $f$ feldspato; $y$ - gesso.] reflections (as a smectite-type), whereas BG presented the narrowest montmorillonite reflections, indicating a better crystalline arrangement. BG contained quartz and feldspar as impurities in lower amounts than BR, which also presented a little gypsum content. The diffractograms confirmed the presence of a dioctahedral structure since they present the (060) reflection, between 61 and $62^{\circ} 2 \theta$ [22, 23]. XRD patterns of the purified bentonites, BRp and BGp (Fig. 1b), showed greater intensities of the montmorillonite reflections regarding to impurities, indicating that the montmorillonite component was concentrated in bentonites.

Fig. 2 shows the FTIR spectra of bentonites before and after purified conditions. Absorption bands corresponding to the montmorillonite structure were identified [24-26]. Absorption at $3630 \mathrm{~cm}^{-1}$ was attributed to $\mathrm{Al}-\mathrm{OH}$ stretches of the octahedral layer. The band at $3438 \mathrm{~cm}^{-1}$ was due to the $\mathrm{H}-\mathrm{OH}$ vibrations of the hydrogen bridging bonds of the water adsorbed on the interlayer structure and/or water. This is a manifestation of the hydration state of the samples. The intense band at $1035 \mathrm{~cm}^{-1}$ was due to stretching of the Si-O$\mathrm{Si}$ bond related to basal oxygens. The $\mathrm{OH}$ bending bands at 920 and $850 \mathrm{~cm}^{-1}$ were attributed to the deformations of the $\mathrm{Al}-\mathrm{OH}$ and $\mathrm{Mg}-\mathrm{Al}-\mathrm{OH}$ groups, respectively, which confirmed the presence of the dioctahedral smectite. The intensity of the band at $920 \mathrm{~cm}^{-1}$ was lower in BRp, which is consistent with the lower $\mathrm{Al}$ content in the montmorillonite structure. Meanwhile, the band at $850 \mathrm{~cm}^{-1}$ was poorly visible in both samples due to the low $\mathrm{Mg}$ content. The signal at $791 \mathrm{~cm}^{-1}$ was assigned to the $\mathrm{Si}-\mathrm{O}$ vibration characteristic of quartz [27], which also had bands that overlapped with the Si-O of the $1035 \mathrm{~cm}^{-1}$ tetrahedral layer. This band was more intense in natural samples due to the higher quartz content. The bands at 522 and $467 \mathrm{~cm}^{-1}$ corresponded to the vibration of the Si-O-Al bonds in the octahedral layer and $\mathrm{Si}-\mathrm{O}$ in the tetrahedral layer, respectively [28].

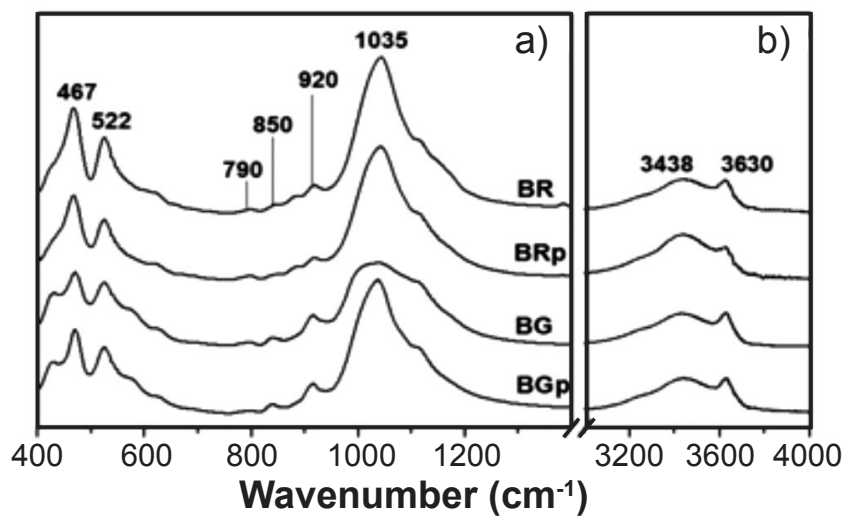

Figure 2: FTIR spectra of natural bentonites and their purified fractions in the $400-1400 \mathrm{~cm}^{-1}$ (a) and $\mathrm{OH}$ stretching (b) regions.

[Figura 2: Espectros de FTIR de bentonitas naturais e suas frações purificadas nas regiões de $400-1400 \mathrm{~cm}^{-1}$ (a) e estiramento $\mathrm{OH}(b)$.

Fig. 3 shows the results of the DTA-TG studies. The bentonites presented the characteristic curve of its main component, the montmorillonite [29]. The endothermic peak 

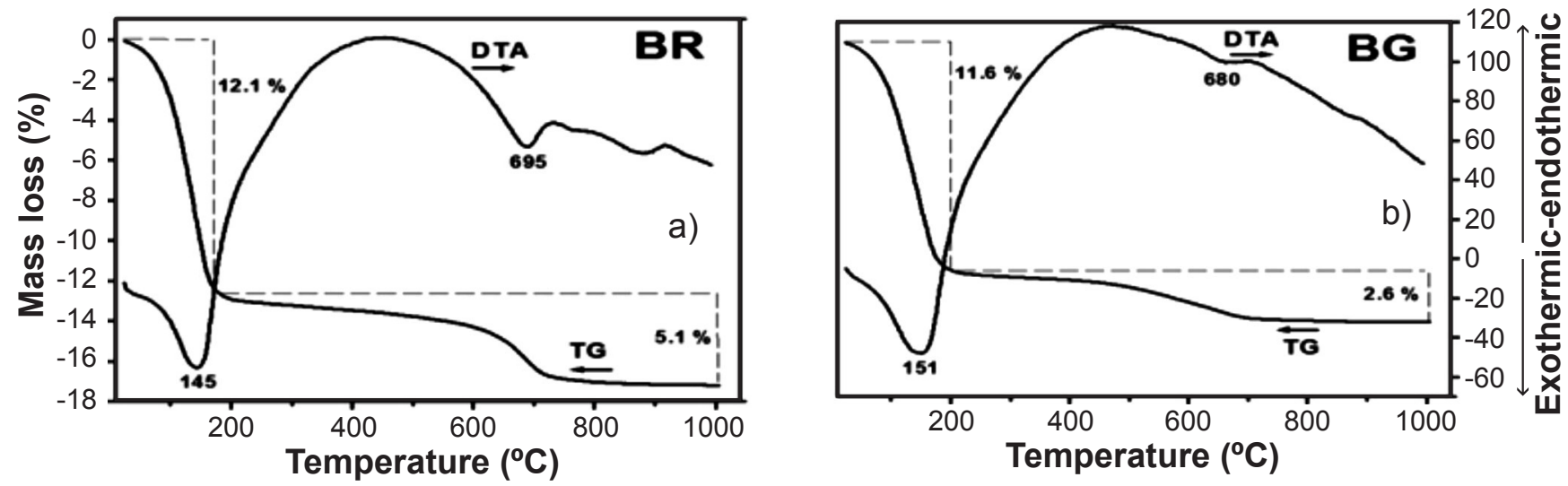

Figure 3: TG and DTA curves of the natural bentonites.

[Figura 3: Curvas de TG e DTA das bentonitas naturais.]
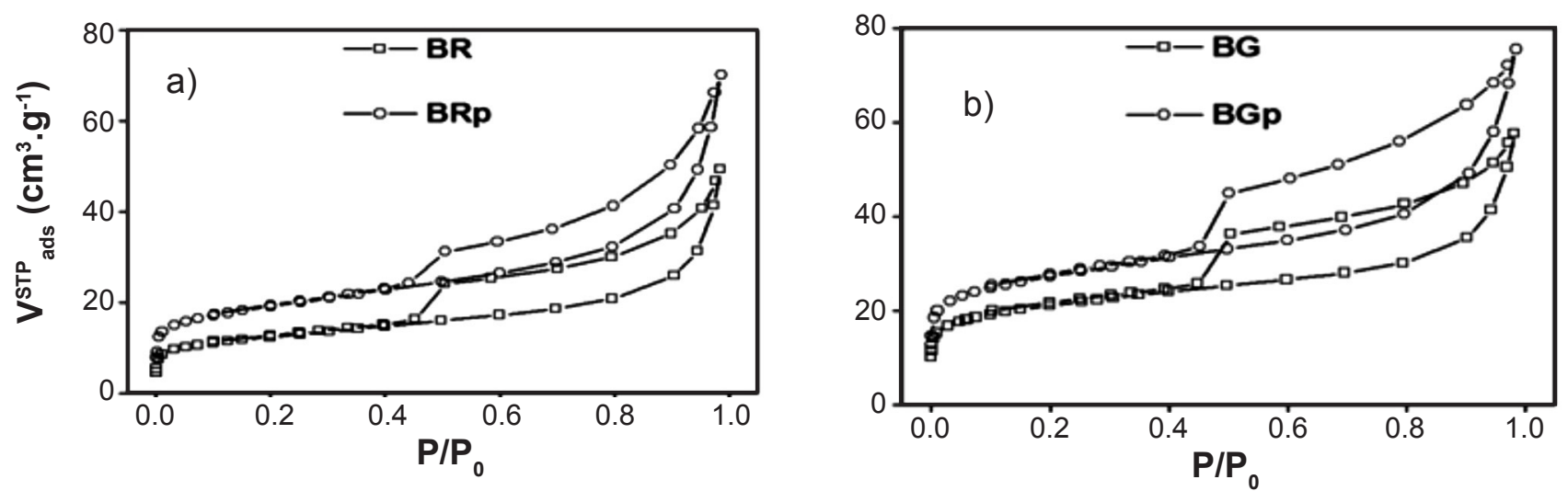

Figure 4: Adsorption-desorption $\mathrm{N}_{2}$ isotherms of the samples under study.

[Figura 4: Isotermas de adsorção-dessorção de $N_{2}$ das amostras em estudo.]

Table II - Textural characteristics ${ }^{\mathrm{a}}$ and CEC of natural and purified bentonites.

[Tabela II - Características texturais e CTC das bentonitas naturais e purificadas.]

\begin{tabular}{cccccc}
\hline & $\mathrm{S}_{\mathrm{BET}}\left(\mathrm{m}^{2} / \mathrm{g}\right)$ & $\mathrm{V}_{\mathrm{T}}\left(\mathrm{cm}^{3} / \mathrm{g}\right)$ & $\mathrm{V}_{\mu \mathrm{p}}\left(\mathrm{cm}^{3} / \mathrm{g}\right)$ & $\mathrm{V}_{\mathrm{mp}}\left(\mathrm{cm}^{3} / \mathrm{g}\right)$ & CEC $(\mathrm{meq} / 100 \mathrm{~g})$ \\
\hline $\mathrm{BR}$ & 45 & 0.08 & 0.02 & 0.06 & 100.7 \\
$\mathrm{BRp}$ & 69 & 0.11 & 0.02 & 0.09 & 106.1 \\
$\mathrm{BG}$ & 77 & 0.09 & 0.01 & 0.08 & 97.9 \\
$\mathrm{BGp}$ & 99 & 0.12 & 0.03 & 0.09 & 160.7 \\
\hline
\end{tabular}

$a_{-} S_{B E T}, V_{\mu p}, V_{m p}, V_{T}:$ specific area, micro and mesoporosity, and total porous volume, respectively, calculated at $P / P_{0} \approx 0.98$ from the data of nitrogen isotherm.

observed between 100 and $250{ }^{\circ} \mathrm{C}$ due to dehydration of the clay (physisorbed and interlayer $\mathrm{H}_{2} \mathrm{O}$ ) occurred at a lower temperature in $\mathrm{BR}$. The respective percentage of weight loss was higher in that sample and was associated with this shift. Based on the above, it is expected that BR contained cations with a higher degree of hydration, which allowed it to retain more $\mathrm{H}_{2} \mathrm{O}$. The second endothermic peak, around $690^{\circ} \mathrm{C}$, was due to the loss of $\mathrm{OH}$ groups from the montmorillonite sheet [30]. This peak was more defined in BR as a consequence of the more accessible removal of these groups due to the lower crystallinity in its structure. The loss of mass in this stage presented values of 5.1 and $2.6 \%$ for BR and BG, respectively. The third stage, around $800-900{ }^{\circ} \mathrm{C}$, corresponded to the destruction of the structure and formation of high-temperature phases (oxides).
The adsorption-desorption $\mathrm{N}_{2}$ isotherms are presented in Fig. 4. There are characteristic behaviors of montmorillonites. They can be classified as type IIb isotherms, related to materials of laminar structure. At low relative pressures, a low adsorption was observed, which was more noticeable in natural samples and suggested that there was a low contribution of micropores to the structure. In each sample, the hysteresis cycle indicated the presence of mesopores due to interparticle spaces and can be classified as type H3, associated with aggregates of laminar particles according to IUPAC classification [17, 31]. Finally, the increase of adsorption at high relative pressures suggested the presence of larger pores. The textural properties presented in Table II are concordant with the values reported for montmorillonites [32]. They evidenced materials that are mainly mesoporous 
Table III - Chemical composition (wt $\%$ ) and $\mathrm{S}_{\mathrm{BET}}\left(\mathrm{m}^{2} / \mathrm{g}\right)$ of natural, purified and Ca-modified bentonites.

[Tabela III - Composição química (\% em massa) e $S_{B E T}\left(\mathrm{~m}^{2} / \mathrm{g}\right)$ das bentonitas natural, purificada e modificada com Ca.]

\begin{tabular}{ccccccccccccc}
\hline & $\mathrm{SiO}_{2}$ & $\mathrm{Al}_{2} \mathrm{O}_{3}$ & $\mathrm{Fe}_{2} \mathrm{O}_{3}$ & $\mathrm{MnO}$ & $\mathrm{MgO}$ & $\mathrm{CaO}$ & $\mathrm{Na}_{2} \mathrm{O}$ & $\mathrm{K}_{2} \mathrm{O}$ & $\mathrm{TiO}_{2}$ & $\mathrm{LOI}$ & $\mathrm{SiO}_{2} / \mathrm{MO}$ & $\mathrm{S}_{\text {BET }}$ \\
\hline BR & 57.71 & 18.12 & 4.79 & 0.05 & 2.95 & 1.66 & 2.63 & 0.34 & 0.23 & 10.76 & 1.88 & 45 \\
BRp & 58.12 & 19.25 & 4.99 & 0.04 & 3.14 & 1.42 & 2.98 & 0.28 & 0.23 & 8.97 & 1.80 & 69 \\
BR-2i & 57.18 & 18.67 & 4.84 & 0.04 & 2.95 & 2.78 & 0.89 & 0.27 & 0.23 & 13.05 & 1.86 & 37 \\
BR-10m & 40.54 & 12.56 & 2.79 & 0.03 & 2.02 & 16.68 & 2.15 & 0.22 & 0.14 & 23.33 & 1.11 & 9 \\
\hline BG & 59.64 & 17.06 & 1.48 & 0.02 & 3.38 & 1.50 & 2.64 & 0.58 & 0.25 & 14.32 & 2.22 & 77 \\
BGp & 60.41 & 19.17 & 1.63 & 0.01 & 4.20 & 1.20 & 3.00 & 0.23 & 0.23 & 10.28 & 2.04 & 99 \\
BG-2i & 60.35 & 17.54 & 1.58 & 0.02 & 3.74 & 3.27 & 0.90 & 0.55 & 0.25 & 12.42 & 2.17 & 43 \\
BG-10m & 37.07 & 10.13 & 0.65 & 0.01 & 2.06 & 20.50 & 1.40 & 0.30 & 0.12 & 28.46 & 1.05 & 4 \\
\hline
\end{tabular}

Table IV - Calculated structural formulae for BRp and BGp. [Tabela IV - Fórmulas estruturais calculadas para BRp e BGp.]

\begin{tabular}{cc}
\hline & Formula \\
\hline BRp & $\left(\mathrm{Si}_{7.72} \mathrm{Al}_{0.28}\right)\left(\mathrm{Al}_{2.74} \mathrm{Fe}_{0.50} \mathrm{Mg}_{0.62} \mathrm{Mn}_{0.004} \mathrm{Ti}_{0.02}\right)\left(\mathrm{Na}_{0.77} \mathrm{Ca}_{0.20} \mathrm{~K}_{0.05}\right) \mathrm{O}_{20}(\mathrm{OH})_{4}$ \\
BGp & $\left(\mathrm{Si}_{7.93} \mathrm{Al}_{0.07}\right)\left(\mathrm{Al}_{2.90} \mathrm{Fe}_{0.16} \mathrm{Mg}_{0.82} \mathrm{Mn}_{0.002} \mathrm{Ti}_{0.02}\right)\left(\mathrm{Na}_{0.76} \mathrm{Ca}_{0.17} \mathrm{~K}_{0.04}\right) \mathrm{O}_{20}(\mathrm{OH})_{4}$ \\
\hline
\end{tabular}

with the very little contribution of micropores, which was in agreement with the porous structure proposed previously, since the contribution of microporous can be related mainly to spaces formed in the defective borders of the tactoid structure [12]. Among the natural bentonites, BG presented greater surface area than BR. After the removal of impurities and concentration of the montmorillonite the $\mathrm{S}_{\mathrm{BET}}$ increased.

The chemical composition and the loss of ignition (LOI) of the natural and purified bentonites presented in Table III correspond to the values reported for bentonite [33]. Among the natural bentonites, $\mathrm{BR}$ had a higher proportion of $\mathrm{Al}_{2} \mathrm{O}_{3}$. Meanwhile, $\mathrm{BG}$ had the highest $\mathrm{SiO}_{2}$ value [34]. With respect to iron oxide, ocher bentonite had the highest value. The presence of calcium, sodium and potassium corresponded to interlaminar cations, feldspars and gypsum, determined by $\mathrm{XRD}$. The separation of impurities in bentonites, determined by XRD, was confirmed by chemical analyzes. The lower percentages of $\mathrm{K}_{2} \mathrm{O}$ and $\mathrm{CaO}$ indicated feldspar removal. In BRp the decrease of $\mathrm{CaO}$ was also due to gypsum removal. The decrease in the $\mathrm{SiO}_{2} / \mathrm{MO}$ ratio indicated quartz removal and consequently smectite increase. Applying Moore and Reynolds' method the structural formulae of BRp and BGp were calculated (Table IV). From the structural load analysis, BGp contained a montmorillonite with low tetrahedral substitution. As regards the octahedral layer, it contained more aluminum in relation to $\mathrm{BRp}$ and higher $\mathrm{Mg}^{2+}$ content, whereby had a lower dioctahedral character and consequently fewer holes in the structure. For its part, the BRp sample presented in the octahedral layer greater isomorphic substitution of $\mathrm{Al}^{3+}$ by $\mathrm{Fe}^{3+}$, without producing a charge deficit. The structural negative charge of the montmorillonites, resulting from isomorphic substitutions, and edge defects in the basic medium [35], gave it a greater availability of sites to adsorb cations, since these compensate the laminar charge. According to the analysis of the structural formula of the purified bentonites, the greater substitution of iron in the octahedral layer conferred a lower structural crystallinity to BRp and consequently its reactivity increase. Thus, and according to the above mention, BR and BG had high montmorillonite content and structural differences between them. As for CEC, natural bentonites had similar values (Table II). After purification process, an increase in the CEC value was observed for BG sample. This can be attributed to inert removal, the higher octahedral load due to the higher content of $\mathrm{Mg}^{2+}$ and a slight total load deficit gave by the lower contribution of the ions $\mathrm{Na}^{+}, \mathrm{Ca}^{2+}$ and $\mathrm{K}^{+}$ in BGp.

Bentonite clays with thermal treatment: Fig. 5a shows the XRD patterns of the samples under study between 3 and $11^{\circ} 2 \theta$. Natural bentonites, present as hydrated crystallites, exhibited (001) reflection peaks around $6^{\circ} 2 \theta$ and the nearly symmetrical peak suggested relatively uniform layer stacking along the $\mathrm{c}$ axis. With the treatment at $100{ }^{\circ} \mathrm{C}$, a large number of hydrated phase crystallites lost most of their water and the dehydrated phase caused the sheets to approach, while the spacing between them decreased. Relatively uniform stacking of layers along the c-axis was lost. As a consequence, the intensity of the (001) reflection peaks decreased and they were asymmetrical and not very acute [36]. These effects were more noticeable in BR-100 and were associated with the lower crystallinity of the starting material. The evolution of the dehydrated phase continued until $300^{\circ} \mathrm{C}$. A new peak became more prominent at higher values of $2 \theta$, which was narrower and symmetrical in BR-300. The difference between the (001) reflection values of BG and the thermally treated BG-100 and BG-300 was low. This was attributed to the more ordered structure of the starting material, whereby the thermal energy supplied was not sufficient to readily and rapidly remove 
the $\mathrm{H}_{2} \mathrm{O}$ molecules from the interlayer. This was consistent with the results of DTA-TG in which the first endothermic peak of BG was at a higher temperature than in BR. At $500{ }^{\circ} \mathrm{C}$ dewatering was completed, and dehydroxylation and irreversible modification of the expandable sheet structure were initiated. The (001) reflection decreased to the value corresponding to the collapse of the sheets $(9.6 \AA)$. However, uniformity patterns of layer stacking along the c-axis again occurred as a consequence of a new rearrangement, different from that of the natural material.

Figs. $5 \mathrm{~b}$ and $5 \mathrm{c}$ present the FTIR spectra of the natural and heat-treated samples. The treatment up to $500{ }^{\circ} \mathrm{C}$ gradually decreased the band intensity at $3436 \mathrm{~cm}^{-1}$, in addition to its widening, due to the elimination of $\mathrm{H}_{2} \mathrm{O}$. The low intensity of this band in samples B-500 indicated the presence of traces of water. At higher temperatures loads arising from isomorphic substitutions were localized in some of the oxygens, resulting in strong hydrogen bridging bonds in the $\mathrm{OH}$ groups that were not eliminated. As for the bands around $3620 \mathrm{~cm}^{-1}$, no appreciable changes were observed with the treatment up to $300{ }^{\circ} \mathrm{C}$, evidencing the stability of the montmorillonite structure in these samples. Nevertheless, the intensity decreased slightly in the B-500 samples as a result of the initiation of dehydroxylation and the bands near 915 and $840 \mathrm{~cm}^{-1}$ practically disappeared
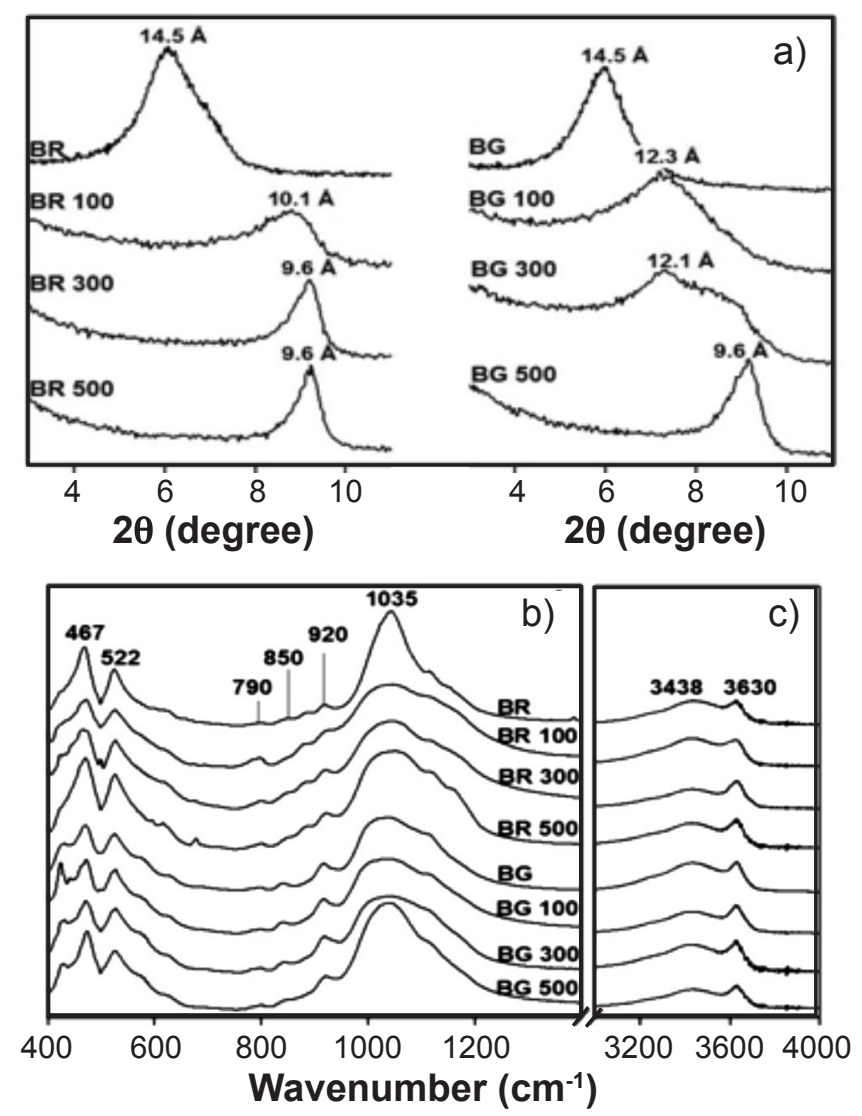

Figure 5: XRD patterns (a) and FTIR spectra in $400-1400 \mathrm{~cm}^{-1}$ (b) and $\mathrm{OH}$ stretching (c) regions of heat treated bentonites.

[Figura 5: Difratogramas de raios X (a) e espectros de FTIR nas regiões de 400-1400 $\mathrm{cm}^{-1}$ (b) e estiramento de $\mathrm{OH}(\mathrm{c})$ de bentonitas tratados termicamente.] irreversibly changing the structure.

Bentonite clays with aggregate of $\mathrm{Ca}$ : Fig. $6 \mathrm{a}$ shows the XRD patterns of the samples in the region corresponding to the (001) reflection. Relatively large and asymmetric diffraction peaks were observed for natural bentonites. This was attributed to the different states of hydration of the interlaminar ions, since the value of (001) reflection depends on the characteristics of these ions, besides being a function of the origin of the laminar charge and the hydration state of the sample [37]. With purification, the value of (001) reflection increased due to the removal of impurities. The peaks of the samples homoionized with $\mathrm{Ca}$ were better defined and the (001) reflection spacing was also larger than the corresponding natural materials. The increase in basal spacing indicated that $\mathrm{Ca}^{2+}$ ions reached the interlaminar sites replacing $\mathrm{Na}^{+}$and $\mathrm{K}^{+}$, which had lower hydration energies. According to the literature, sodium montmorillonites have (001) reflection peak near $13.5 \AA$ [38]. However, in those homoionized with $\mathrm{Ca}^{2+}$, the ion is coordinated with 6 molecules of $\mathrm{H}_{2} \mathrm{O}$ and (001) reflection is observed around 15 $\AA[11,39]$. Thus, an increase of (001) reflection in the calcium samples was expected. The mixtures B-10m showed (001)
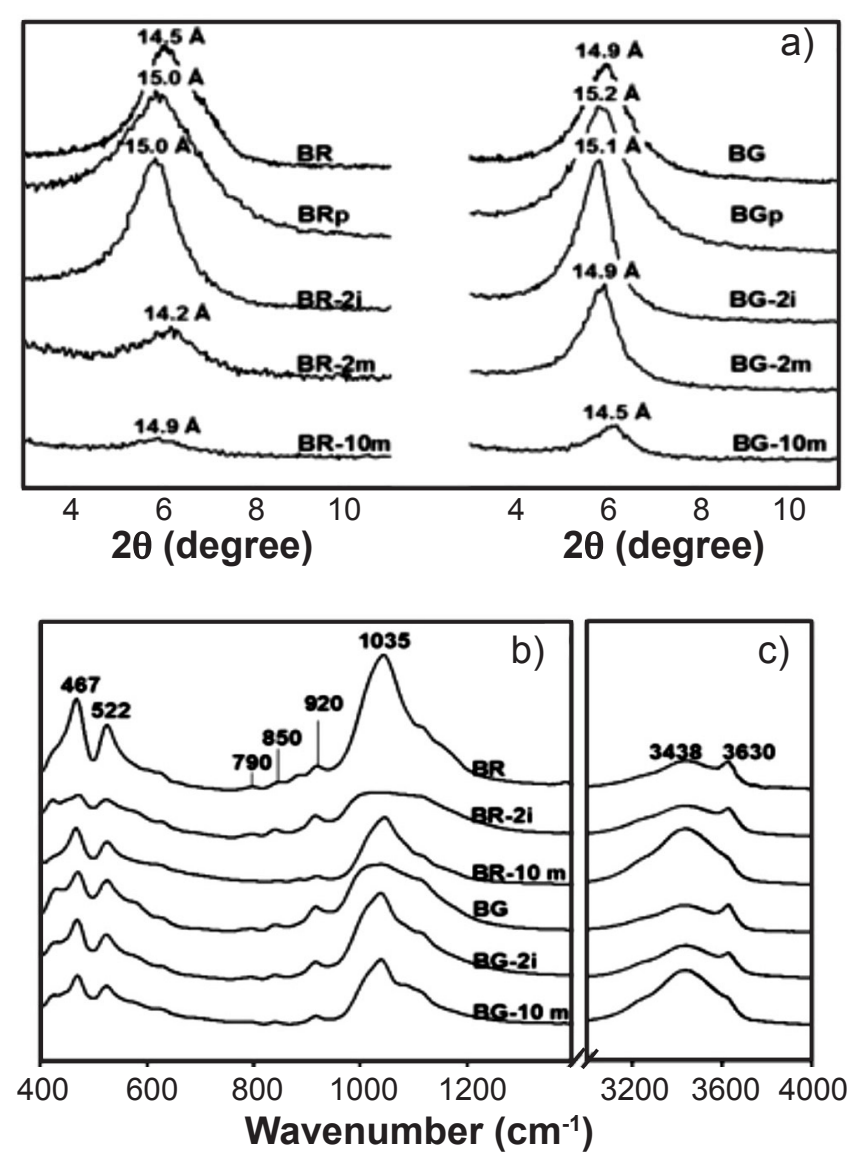

Figure 6: XRD patterns (a) and FTIR spectra in $400-1400 \mathrm{~cm}^{-1}$ (b) and $\mathrm{OH}$ stretching (c) regions of bentonites (natural, purified and with subsequent addition of $\mathrm{Ca}$ ).

[Figura 6: Difratogramas de raios X (a) e espectros de FTIR nas regiões de 400-1400 $\mathrm{cm}^{-1}$ (b) e estiramento de $\mathrm{OH}(\mathrm{c})$ de bentonitas naturais, purificadas e com posterior adição de Ca.] 
reflection close to $14.7 \AA$. In them, the smectite was diluted by the presence of $\mathrm{CaCl}_{2}$ causing distortion in crystallinity and short order stacking. Consequently, the (001) reflection peaks reduced their intensity and were wide and poorly defined. A similar effect was observed in samples B-2m. In these, $d_{(001)}$ decreased with respect to its analogs prepared by the exchange pathway, B-2i. Thus, having (001) reflection close to that of natural materials, it was predicted that the mechanical mixture did not allow the $\mathrm{Ca}$ to be incorporated into the interlayer as did the ion exchange. Figs. $6 \mathrm{~b}$ and $6 \mathrm{c}$ show the FTIR spectra of the samples. In samples B-2i, like the B, the peaks at 3630 and $3438 \mathrm{~cm}^{-1}$ were well differentiated. However, the band at $3438 \mathrm{~cm}^{-1}$ increased relative to that of the structural $\mathrm{OH}$, due to the higher hydrophilicity of the samples. The addition of $\mathrm{Ca}$ by the mechanical via induced even more the increase of the band at $3438 \mathrm{~cm}^{-1}$ causing the overlap of the same with that corresponding to $3630 \mathrm{~cm}^{-1}$, as a consequence of the increase of hydrophilicity.

Fig. 7 shows the adsorption isotherms of the natural bentonites and with the addition of $\mathrm{Ca}$. As their respective starting materials, the samples had type IIb isotherms. In $\mathrm{B}-2 \mathrm{i}$, the adsorption branch had lower values than in samples $\mathrm{B}$, up to about $\mathrm{P} / \mathrm{P}_{0}=0.85$. Then the isotherm deviated and a marked increase began, which was attributed to the presence of larger mesopores. The negative structural charge of the starting materials, the alkaline $\mathrm{pH}$ of their suspensions and the presence of $\mathrm{Ca}^{2+}$ in the homoionized samples promoted
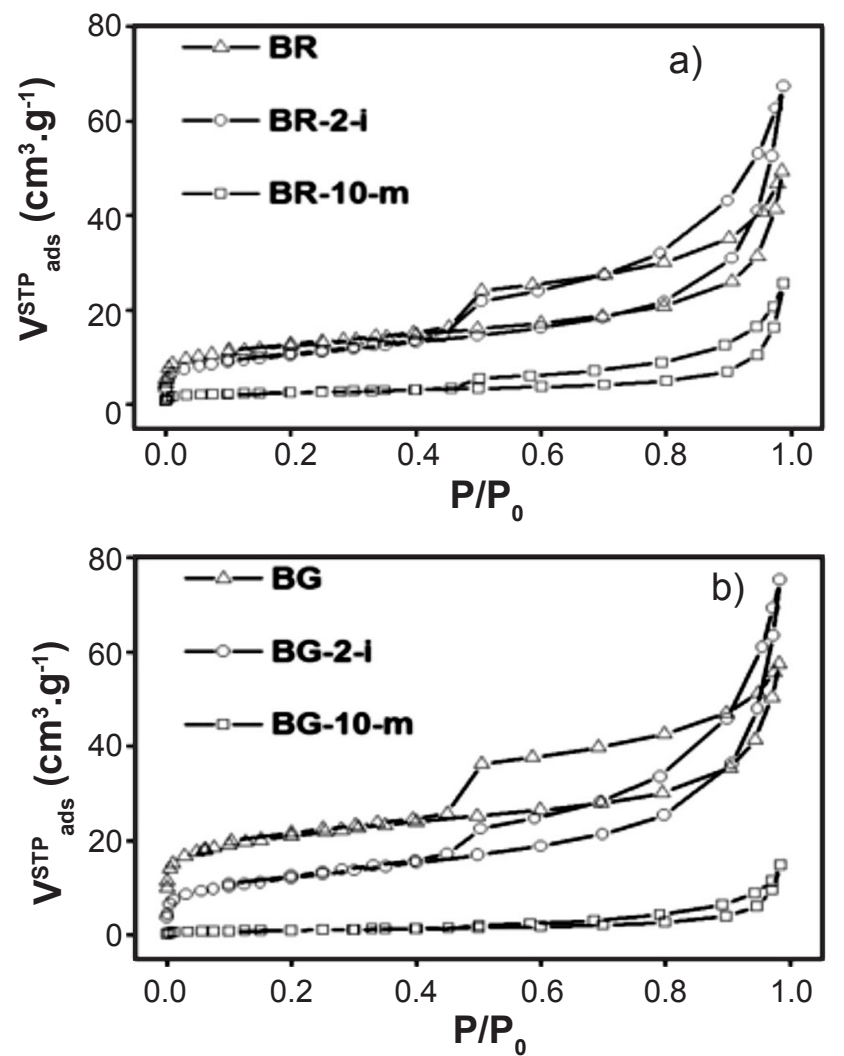

Figure 7: Adsorption-desorption $\mathrm{N}_{2}$ isotherms of natural bentonites and with subsequent addition of $\mathrm{Ca}$.

[Figura 7: Isotermas de adsorção-dessorção de $N_{2}$ de bentonitas naturais e com subsequente adição de Ca.] the association between particles, since this ion, with higher charge density, favored the union between negative faces and between negative faces and edges. Thus, the larger particle decreased the available surface area for adsorption of $\mathrm{N}_{2}$. In samples B-10m, there was a decrease in the volume of $\mathrm{N}_{2}$ adsorbed in the entire range of relative pressures, due to the dilution of smectite and eventual occlusion of the material pores by $\mathrm{CaCl}_{2}$. According to the above, the modified materials had lower $\mathrm{S}_{\mathrm{BET}}$ values (Table III) and BG samples showed the greatest decrease. The results of the chemical analyses of the Ca-modified bentonites are shown in Table III. These samples showed the highest values of $\mathrm{CaO}$ content. In samples B-2i, Ca replaced the exchange cations and the $\mathrm{SiO}_{2} / \mathrm{MO}$ ratio remained virtually unchanged indicating that the smectite content remained constant. Meanwhile, in samples $\mathrm{B}-10 \mathrm{~m}$, there was a decrease in the $\mathrm{SiO}_{2} / \mathrm{MO}$ ratio due to the dilution of the mineral in these samples.

\section{Adsorption of water between 11-98\% RH at $25^{\circ} \mathrm{C}$}

Natural and purified bentonite clays: Fig. 8a presents the water adsorption results of the samples under study. It was observed that the desiccant capacity was higher in the fine fraction. At high RH all samples showed good behavior.
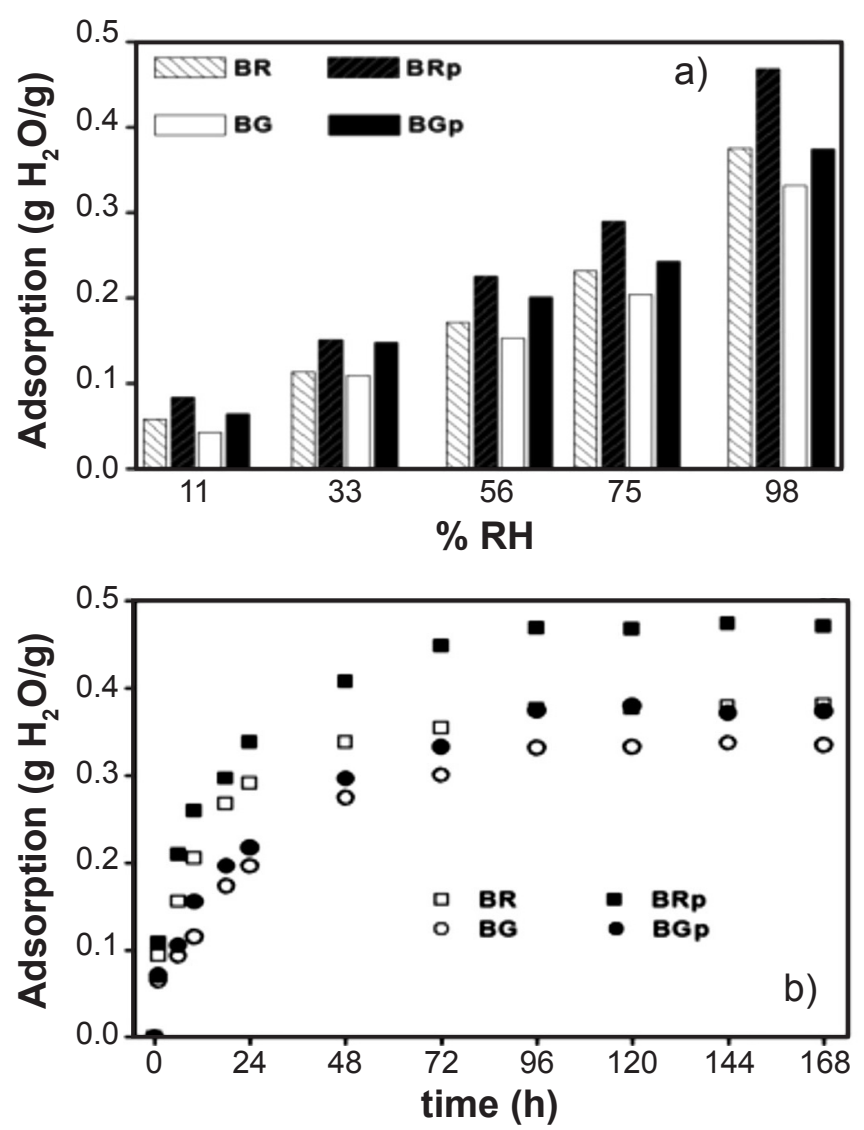

Figure 8: Adsorption of water between 11-98\% RH (a) and kinetics of adsorption at $98 \%$ RH (b) of natural and purified bentonites.

[Figura 8: Adsorção de água entre 11-98\% de umidade relativa (RH) (a) e cinética de adsorção em $98 \%$ RH (b) de bentonitas naturais e purificadas.] 
From the alkaline $\mathrm{pH}$ analysis of the clay suspensions and according to the literature [40], surface negative charges are neutralized by the adsorption of hydratable cations and/ or water molecules bound through the positive pole. The adsorption order was: $\mathrm{BR}>\mathrm{BG} ; \mathrm{BRp}>\mathrm{BGp}$. This was related to structural characteristics of BR, such as higher hydrophilic content (higher structural load), higher dioctahedral character and lower crystallinity (greater isomorphic substitution), which made it more reactive [41]. The adsorption kinetics at $98 \%$ RH (Fig. 8 b) indicated that the concentration of the clay mineral gave rise to a higher adsorption at the same time of contact. The adsorption increased rapidly in the first 24 $\mathrm{h}$ and then decreased as the equilibrium time approached, which was reached at around $96 \mathrm{~h}$. The high initial adsorption velocity was attributed to the availability of a large number of hydrophobic adsorption sites (interlaminar cations and edge defects). When these sites gradually filled up, the adsorption became slow and the kinetics became dependent on the rate at which the water was transported from the covered phase to sites that were not yet covered.

Bentonite clays with heat treatment: for a given $\mathrm{RH}$, the retention values increased from the natural samples, dried at 70 ${ }^{\circ} \mathrm{C}$, to those thermally treated at $300{ }^{\circ} \mathrm{C}$ (Fig. 9a) because the heat treatment up to $300{ }^{\circ} \mathrm{C}$ caused loss of physisorbed water. This indicated a strong relationship between dehydration
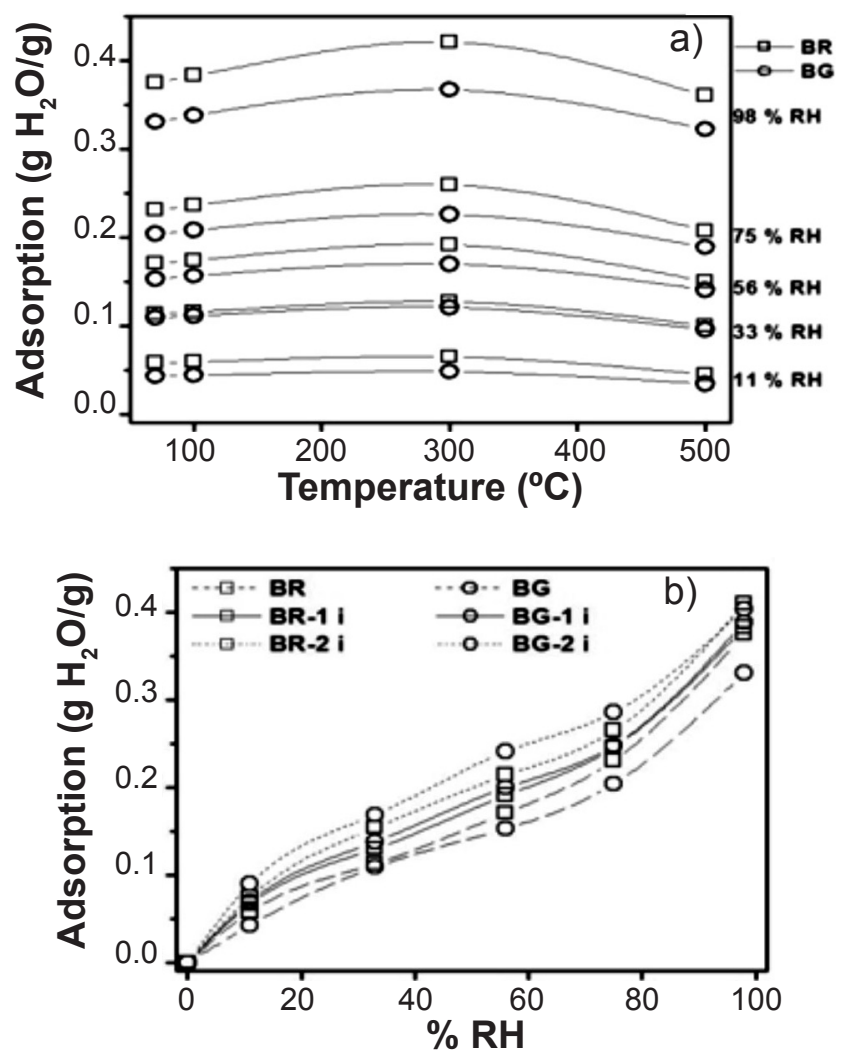

Figure 9: Adsorption of water in natural bentonites and with heat treatment (a), and water adsorption isotherms of bentonites modified with $\mathrm{Ca}$ by ion exchange (b).

[Figura 9: Adsorção de água em bentonitas naturais e com tratamento térmico (a) e isotermas de adsorção de água de bentonitas modificadas com Ca por troca iônica (b).] induced loss of mass and desiccant capacity. Meanwhile, the desiccant capacity of the B-500 samples was reduced with respect to the natural one. In such calcined samples, upon modification of the expandable structure, the access of water molecules was reduced, resulting in a lower desiccant capacity.

Bentonite clays with aggregate of $\mathrm{Ca}$. Via ion exchange: the adsorption isotherms of the samples are shown in Fig. $9 b$. For a given $\mathrm{RH}$, the adsorption increased with the $\% \mathrm{Ca}$ incorporated. Also, the shape of the isotherms was similar and the adsorption increased rapidly to $11 \% \mathrm{RH}$. Then there was a reduction in retention velocity up to about $56 \% \mathrm{RH}$, with a point of inflection in the curve because the second layer of water began to form gradually [42]. Above $75 \%$ $\mathrm{RH}$ adsorption increased rapidly as new water molecules condensed on the outer hydrophilic surfaces of the structure (surface siloxanes, isomorphic substitution sites, edges, exposed silanol and aluminol groups) [43], and the curve became again concave upwards. The preference of water molecules for the $\mathrm{Ca}^{2+}$, relative to the $\mathrm{Na}^{+}$, primary interlayer ion in samples B-2i and B was deduced, which would be associated with the higher charge density of the first ion. In order to corroborate it, the geometry of $\mathrm{Ca}^{2+}$ and $\mathrm{Na}^{+}$hydrates was optimized and the corresponding parameters were determined (Table V). The MOPAC 2012 software and the semi-empirical method PM6 [44] were used. According to the hydration energies (shown below), hydrates were selected and they corresponded to $\mathrm{Ca}\left(\mathrm{H}_{2} \mathrm{O}\right)_{5}{ }^{2+}$ and $\mathrm{Na}\left(\mathrm{H}_{2} \mathrm{O}\right)_{2}{ }_{2}^{+}$. It was also observed that throughout the $\mathrm{RH}$ interval the retention was higher for the BR samples.

Table V - Parameters of $\mathrm{Ca}^{2+}$ and $\mathrm{Na}^{+}$hydrates determined by semi-empirical calculations.

[Tabela V - Parâmetros dos hidratos de $\mathrm{Ca}^{2+}$ e $\mathrm{Na}^{+}$ determinados por cálculos semiempíricos.]

\begin{tabular}{cccc}
\hline Hydrate & $\begin{array}{c}\mathrm{E}_{\text {formation }} \\
(\mathrm{kcal} / \mathrm{mol})\end{array}$ & $\begin{array}{c}\text { Volume } \\
\left(\AA^{3}\right)\end{array}$ & $\begin{array}{c}\text { Charge } \\
\text { density }\end{array}$ \\
\hline $\mathrm{Ca}\left(\mathrm{H}_{2} \mathrm{O}\right)_{5}{ }^{2+}$ & -13.5 & 462.5 & 0.0043 \\
$\mathrm{Na}\left(\mathrm{H}_{2} \mathrm{O}\right)_{2}{ }^{+}$ & -2.2 & 273.1 & 0.0037 \\
\hline
\end{tabular}

Mechanical track: for a given RH, the adsorption increased with the \% Ca added (Fig. 10). Similar results were reported in other studies [11]. The higher retention of the mixtures was attributed to the increase of hydrophilic sites provided by both the clay and the $\mathrm{CaCl}_{2} \cdot 2 \mathrm{H}_{2} \mathrm{O}$ salt. This salt, dispersed in the clay particles, increased its contact surface with respect to the bulk salt, whereby it admitted greater adsorption by capturing water by bridging hydrogen bonds. Consequently, other molecules were adsorbed, through van der Waals forces, into the active sites of the clay. It was observed that the form of isotherms was similar to $3 \% \mathrm{Ca}$. Then they became almost linear since the adsorption was mainly due to $\mathrm{CaCl}_{2} \cdot 2 \mathrm{H}_{2} \mathrm{O}$ and to a lesser extent to bentonite. On the other hand, up to $10 \% \mathrm{Ca}$, the optimal dispersion of the salt in the clay particles allowed to overcome the problem of forming a film of liquid water thereon during the adsorption. Fig. 11 shows that for 

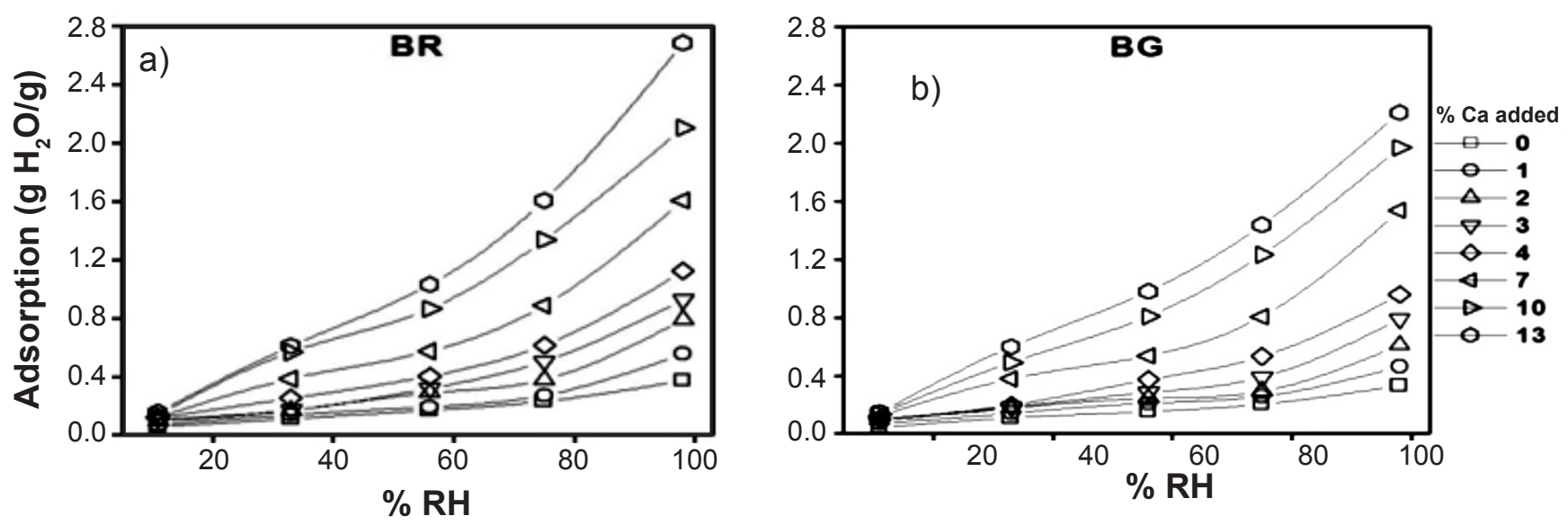

Figure 10: Water adsorption isotherms of bentonites modified with Ca by mechanical mixing.

[Figura 10: Isotermas de adsorção de água de bentonitas modificadas com Ca por mistura mecânica.]

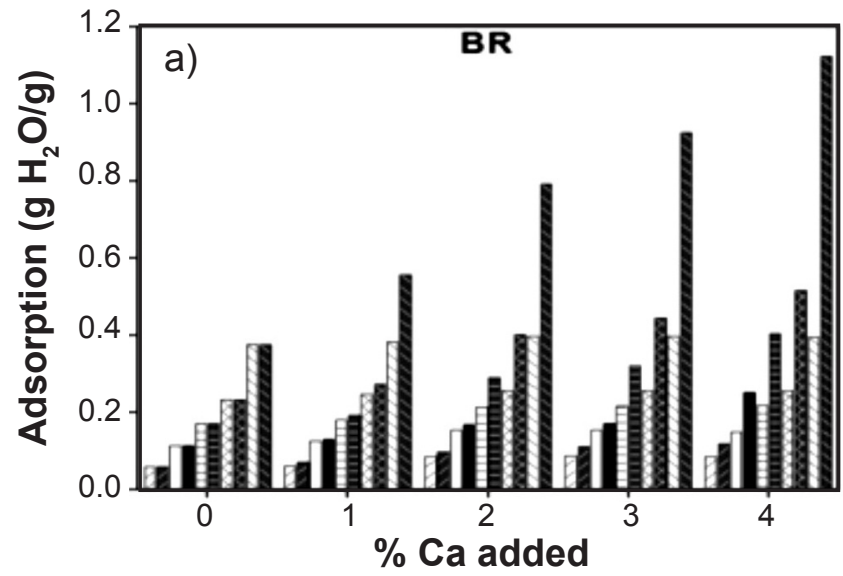

Figure 11: Adsorption in natural and Ca-modified bentonite.

[Figura 11: Adsorção em bentonita natural e modificada por Ca.]

the same amount of $\mathrm{Ca}$ added, $\mathrm{Ca}$ is more favorable for the adsorption when it is added mechanically, due to the high hygroscopicity of the Ca salt. Desiccant mixtures obtained by a simple mechanical mixing can be important in industrial applications, which require desiccants in large quantities and whose price is determined more by the preparation process than by the price of the raw materials.

Kinetic study and hydration energy of $B, B p, B-300, B-2-i$ and $B-10-m$

Pseudo-second order kinetic model: Table VI shows the correlation coefficients of experimental results of the samples under study. It was observed that the proposed model did not adjust the experimental data obtained at $98 \% \mathrm{RH}$ and $25^{\circ} \mathrm{C}$ of samples B, Bp, B-300 and B-2-i, which would indicate adsorbate-adsorbent physisorption processes. Correlation coefficients greater than 0.99 were determined for the mixtures, therefore further analysis would be necessary.

Calculation of hydration energies: Fig. 12 shows the adsorption isotherms of the samples. The BET equation applied to them gave linear relationships in the range of 0 to $0.56 \mathrm{P} / \mathrm{P}_{0}$, which was in agreement with the literature [13]. It should be noted that in B-10-m blends, due to their

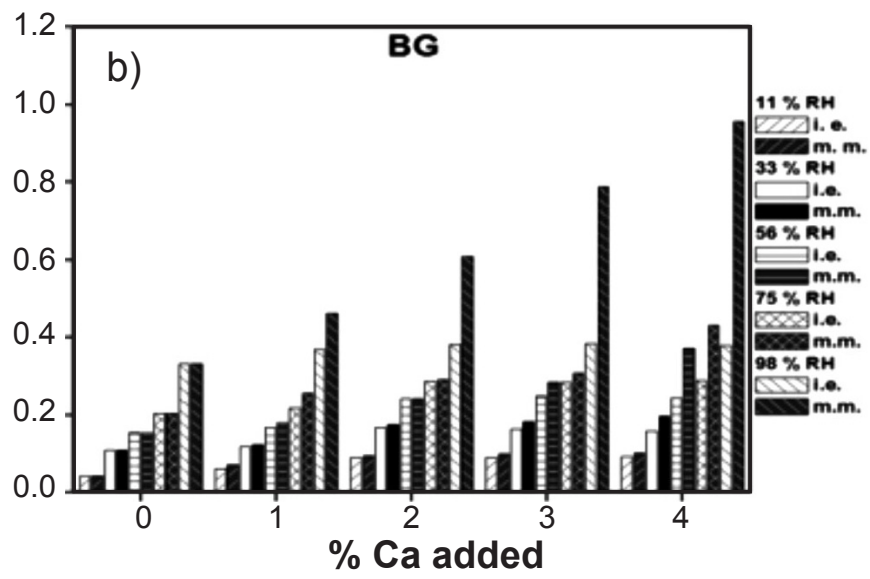

Table VI - Correlation coefficients of experimental results of samples under study adjusted to the kinetic model of pseudo-second order.

[Tabela VI - Coeficientes de correlação dos resultados experimentais das amostras em estudo ajustados ao modelo cinético de pseudossegunda ordem.]

\begin{tabular}{cccccc}
\hline & B & Bp & B-300 & B-2-i & B-10m \\
\hline BR & 0.985 & 0.983 & 0.974 & 0.987 & 0.999 \\
\hline BG & 0.904 & 0.943 & 0.958 & 0.942 & 0.999 \\
\hline
\end{tabular}

biphasic system characteristics, the BET method could not be used. Table VII presents the calculated BET parameters and hydration energies. In all samples, the $\mathrm{X}_{\mathrm{m}}$ was between 0.11 $<\mathrm{P} / \mathrm{P}_{0}<0.33$. In these $\mathrm{RH}$ conditions, the first layer of water molecules in the interlaminar space of the smectite structure was completed. In materials $\mathrm{B}, \mathrm{Bp}$ and $\mathrm{B}-300$, the change cations, $\mathrm{Na}^{+}, \mathrm{Ca}^{2+}$ and $\mathrm{K}^{+}$, determined the distribution of water molecules in their corresponding hydration spheres. With the increase of $\mathrm{RH}$, new water molecules formed hydrogen bonds with the coordinate molecules mentioned above, since they remained indirectly bound to the surface and they did not constitute the higher energy bonds. In this way, the exchange cations were those that contributed greatly to the 

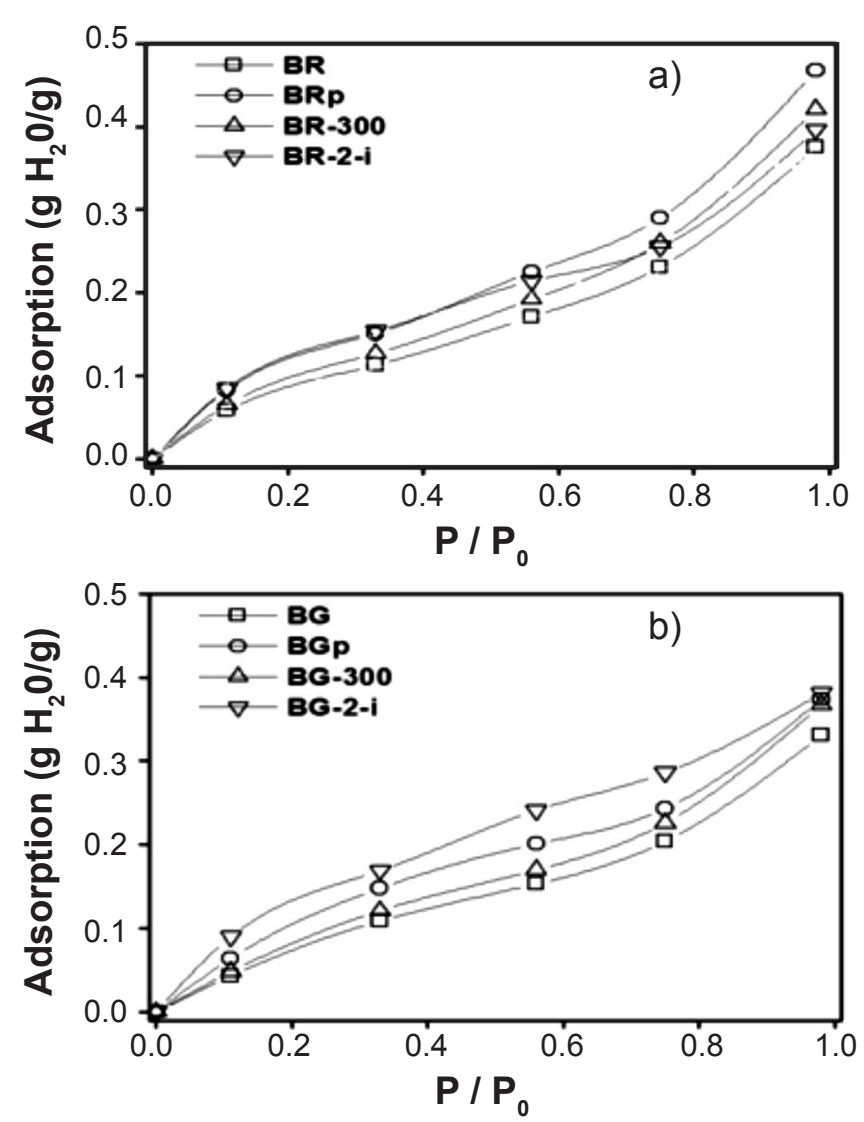

Figure 12: Adsorption isotherms of the bentonites B, Bp, B-300 and B-2-i.

[Figura 12: Isotermas de adsorção das bentonitas B, Bp, B-300 e B-2-i.]

hydration energy $\left(E_{h}\right)$. In samples B and B-300, the values of $E_{h}$ were equal while those of Bp were slightly higher due to the concentration of the smectite mineral, which provided the hydratable cations. Also, these materials had lower values of $\mathrm{E}_{\mathrm{h}}$ with respect to materials $\mathrm{B}-\mathrm{Ca}$. This indicated that the $\mathrm{Ca}^{2+}-$ $\mathrm{H}_{2} \mathrm{O}$ interaction forces were greater than those between $\mathrm{Na}^{+}$ $\mathrm{K}^{+}-\mathrm{H}_{2} \mathrm{O}$. They were sufficient to drive the clay sheets to a $\mathrm{c}$ spacing of 15.01 and $15.12 \AA$ in these calcium samples of BR and $\mathrm{BG}$, respectively. The above mention was attributed to the hydration characteristics of the ion. The optimization of the geometry of the $\mathrm{Ca}^{2+}$ hydrate of the sample B-2i performed as a function of the previously calculated BET energies corresponded to the pentahydrate $\mathrm{Ca}\left(\mathrm{H}_{2} \mathrm{O}\right)_{5}{ }^{2+}$ complex. Thus, a coordination number 5 for $\mathrm{Ca}^{2+}$ was compatible with the spacing $\mathrm{c}$ determined by XRD for these samples. On the other hand, although the BR and BG samples contained high percentages of montmorillonite, the calculations indicated higher hydration energy for the BR samples, which was consistent with their higher desiccant capacity. Thus, a higher load deficit together with a lower structural crystallinity of montmorillonite can justify this behavior.

\section{Solid pelletized adsorbents}

Characterization by FTIR: as expected, the FTIR spectra of the natural and pelletized material of BR and BG showed
Table VII - BET parameters and hydration energies $\left(\mathrm{E}_{\mathrm{h}}\right)$ of samples under study.

[Tabela VII - Parâmetros de BET e energias de hidratação $\left(E_{h}\right)$ das amostras em estudo.]

\begin{tabular}{ccccccc}
\hline \multirow{2}{*}{ Sample } & \multicolumn{2}{c}{$\mathrm{X}_{\mathrm{m}}\left(\mathrm{g} \mathrm{H}_{2} \mathrm{O} / \mathrm{g}\right)$} & \multicolumn{2}{c}{$\mathrm{C}$} & \multicolumn{2}{c}{$\mathrm{E}_{\mathrm{h}}(\mathrm{kcal} / \mathrm{mol})$} \\
& $\mathrm{BR}$ & $\mathrm{BG}$ & BR & BG & BR & BG \\
\hline B & 0.08 & 0.08 & 18.0 & 11.4 & 12.2 & 11.9 \\
Bp & 0.10 & 0.10 & 25.8 & 16.8 & 12.4 & 12.1 \\
B-300 & 0.09 & 0.08 & 17.9 & 11.4 & 12.2 & 11.9 \\
B-2-i & 0.10 & 0.11 & 51.0 & 29.9 & 12.8 & 12.5 \\
\hline
\end{tabular}

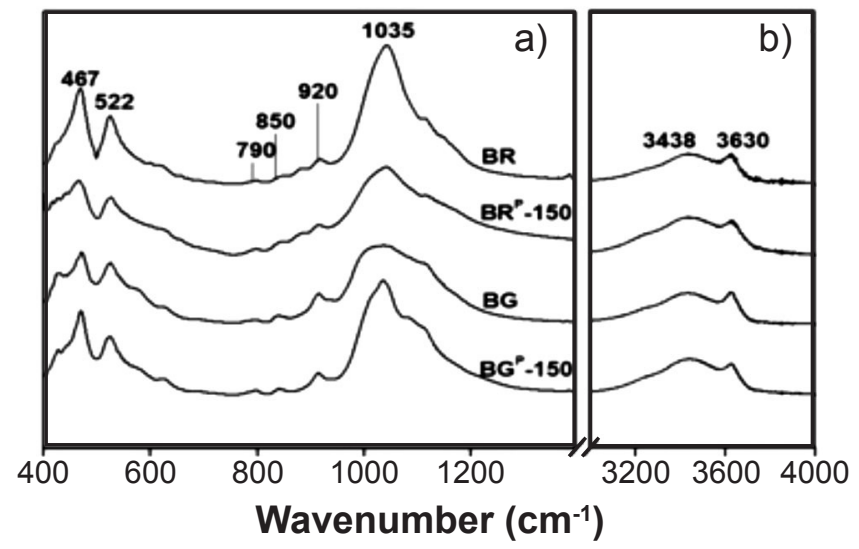

Figure 13: FTIR spectra of powdered and pelletized bentonites in $400-1400 \mathrm{~cm}^{-1}$ (a) and $\mathrm{OH}$ stretching (b) regions.

[Figura 13: Espectros de FTIR de bentonitas pulverizadas $e$ peletizadas nas regiões de $400-1400 \mathrm{~cm}^{-1}$ (a) e estiramento $\mathrm{OH}(\mathrm{b})$.]

fairly coincident vibrational patterns (Fig. 13). In this way, the stability of the smectic structure in the prepared pellets was checked.

Adsorption kinetics at $98 \% \mathrm{RH}$ and $25^{\circ} \mathrm{C}$ : increasing adsorption behavior is shown during the first 8 and 6 days in $\mathrm{BR}^{\mathrm{P}}-150$ and $\mathrm{BG}^{\mathrm{P}}-150$, respectively (Fig. 14a). A limit of adsorption was not evident in the curves, and the same occurred slowly, due to the low exposed surface. Notwithstanding, they maintained the desiccant capacity. At 21 days the adsorption of $\mathrm{BR}^{\mathrm{P}}-150$ and $\mathrm{BG}^{\mathrm{P}}-150$ was 0.43 and $0.39 \mathrm{~g} / \mathrm{g}$, respectively. The moisture removal rate showed that the maximum adsorption occurred during the first contact hours (Fig. 14a). Until day 2 the removal of $\mathrm{BR}^{\mathrm{P}}-150$ exceeded that of $\mathrm{BG}^{\mathrm{P}}$ 150 , then the difference was slight

Comparative study between powdered and pelleted sample, and commercial desiccant: Fig. 14b shows the comparative study between the adsorbents corresponding to the same sample in powder and pellet conditions, and a commercial desiccant, silica gel. They were comparable by both the resistance to the assay conditions and the adsorption capacity. In this way, the technique was improved in terms of handling, without reducing the reactivity required for the effects being pursued.

Regeneration: with regeneration, up to the fifth cycle, the process of evaporation of powder samples at $100{ }^{\circ} \mathrm{C}$ occurred to a large extent (Fig. 15). The adsorptions of B and B-2i 

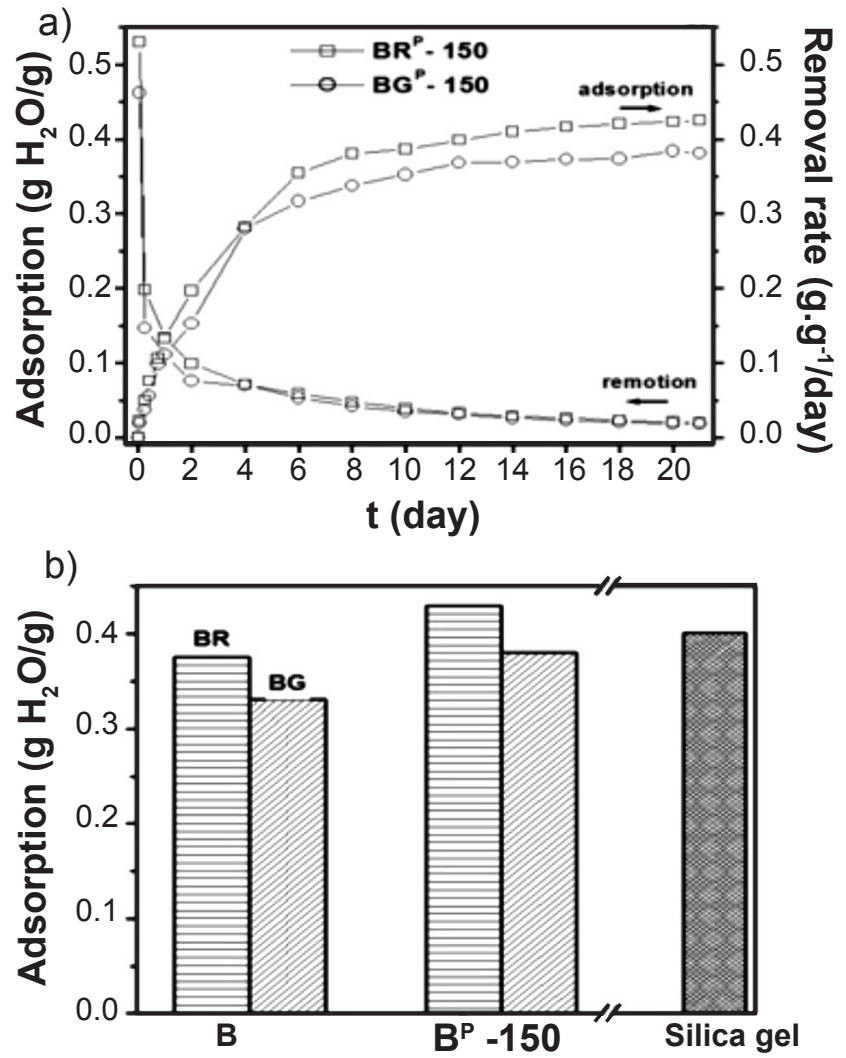

Figure 14: Adsorption kinetics and moisture removal rate of $\mathrm{B}^{\mathrm{P}}$ 150 (a), and adsorption of $\mathrm{B}, \mathrm{B}^{\mathrm{P}}-150$ and silica gel (b).

[Figura 14: Cinética de adsorção e taxa de remoção de umidade do $B^{P}-150$ (a) e adsorção de B, BP-150 e sílica gel (b).]

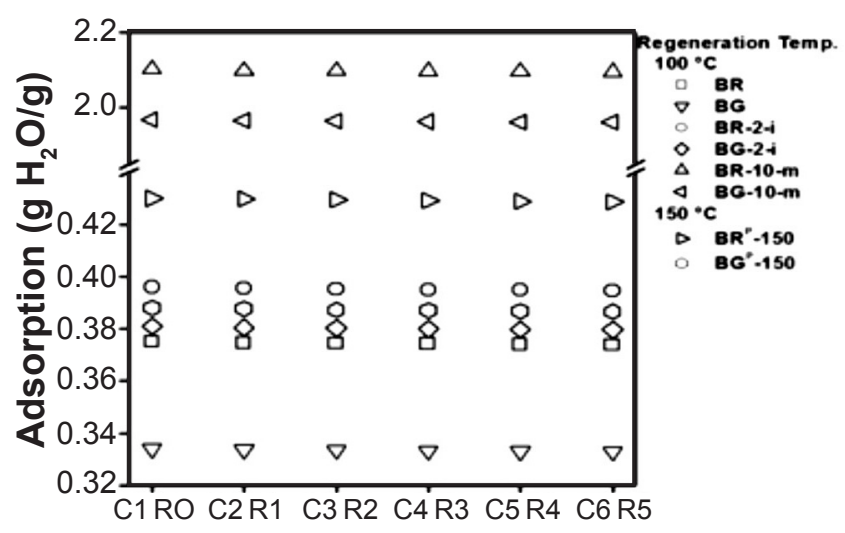

Figure 15: Adsorption evolution after the fifth regeneration in powdered and pelletized materials.

[Figura 15: Evolução da adsorção após a quinta regeneração em materiais em pó e peletizados.]

remained practically constant. However, desiccants B-10-m showed a decrease in adsorption, as a consequence of the greater amount of adsorbed water. During heating, it is feasible that, in addition to water removal, internal rearrangements took place. In this sense, the pressure generated by the volume released would alter the porosity due to the formation of structures that would block access to the pores during the start of a new adsorption process. On the other hand, Fig. 15 shows that it is possible to maintain the desiccant properties of the pellets after 5 consecutive regenerations at $150{ }^{\circ} \mathrm{C}$. Water evaporation was carried out through all the material and the vapor diffused out through its porous structure [22]. During regeneration, the effect of the smallest contact surface of the pellet was compensated by the higher regeneration temperature and the smaller volume released as a consequence of the lower amount of water adsorbed, in relation to sample B-10-m.

\section{CONCLUSIONS}

Two bentonites from different regions of Argentina were characterized, determining mineralogical, structural and textural differences through XRD, FTIR, DTA-TG, $\mathrm{N}_{2}$ adsorption-desorption and chemical analyzes. Two types of bentonites were established, with a higher $(4.8 \%)$ and lower $(<1.5 \%)$ content of $\mathrm{Fe}_{2} \mathrm{O}_{3}$, denominated BR (ocher) and BG (white), respectively. The IR analyzes (characteristic bands), adsorption-desorption of $\mathrm{N}_{2}$ and DTA-TG allowed to confirm that the results were proper and corresponded to bentonite samples. The XRD analysis allowed to identify natural impurities in quartz, feldspar and the presence of gypsum in the BR sample. The identification of characteristic peaks allowed to confirm the presence of smectite as the main clay mineral. The purification of the two types of bentonites was effective. This was confirmed by new analyzes that determined a greater removal of silicon; by XRD the increase in the smectic phase was observed, and by IR analysis an increase in the intensity of characteristic bands and a higher hydrophilic degree was observed. The BR and BG bentonites were thermally modified and $\mathrm{Ca}$ aggregate via ionic and mechanical exchange. After the thermal treatments, (001) reflection shifted towards the collapse of the spacing and the IR analysis indicated a change in bands corresponding to the interlaminar water. The Camodified bentonites showed different structural and textural behavior, and it was evident that the exchange treatment introduced the $\mathrm{Ca}$ in the interlaminar spacing, while the treatment by aggregate did not ensure such mechanism. The adsorption results confirmed the possibility of the application of bentonites characterized as moisture adsorbents. Thus, the adsorption on bentonite was favored by the concentration of the smectite mineral, the drying of the sample, the concentration of aggregated $\mathrm{Ca}$ and the via by which it was incorporated. At $25^{\circ} \mathrm{C}$ and in the same $\mathrm{RH}$ conditions, the adsorption increased in the following order $\mathrm{B}<\mathrm{Bp} \leq \mathrm{B}-300<\mathrm{B}-2-\mathrm{i}<\mathrm{B}-2-\mathrm{m}<\mathrm{B}-10-\mathrm{m}$. The higher adsorption of the $\mathrm{BR}$ versus $\mathrm{BG}$ samples was related to structural characteristics such as higher degree of active hydrophilic sites, higher dioctahedral character and greater global loading of the starting material. An important improvement in adsorption properties was established when bentonite was mixed with $\mathrm{CaCl}_{2} \cdot 2 \mathrm{H}_{2} \mathrm{O}$. Thus, for the same amount of $\mathrm{Ca}$ in the overall composition of the clay, it was more favorable than this as aggregated $\mathrm{Ca}$. With $10 \% \mathrm{Ca}$, an optimum blend for moisture retention was achieved as well as technologically and environmentally satisfactory. The desiccant mixtures were obtained by a simple mechanical mixing. This is important in industrial applications, which 
require desiccants in large quantity and whose price is determined rather by the preparation process than by the price of raw materials. In $\mathrm{B}, \mathrm{Bp}$ and $\mathrm{B}-300$ materials, the hydration energies were smaller with respect to the $\mathrm{B}-\mathrm{Ca}$ materials, because the $\mathrm{Ca}^{2+}-\mathrm{H}_{2} \mathrm{O}$ interaction forces are greater than those between $\mathrm{Na}^{+} / \mathrm{K}^{+}-\mathrm{H}_{2} \mathrm{O}$. The higher hydration energy determined for the BR samples allowed to justify the higher desiccant capacity in relation to the BG samples, even though both contained a high percentage of montmorillonite. In the mixtures, the hydration energy could not be determined by the BET method. With pelletizing, the technique regarding the handling and application of desiccant material was improved, without reducing the reactivity necessary to the effects that are pursued. Thus, making advisable the use of pelletized bentonite as a desiccant material. With the thermal regeneration it was possible to adapt the materials in order to start a new cycle, showing a good behavior in the reversibility. This indicated that the adsorption of water in bentonites is a practically physical process. The results allowed to predict that the clay adsorbents can be reused with high efficiency.

\section{REFERENCES}

[1] R. Grim, N. Guven, Bentonites: geology, mineralogy, properties and uses, Elsevier, New York (2011).

[2] J. Wurm, D. Kosar, T. Clemens, Bull. Int. Inst. Refrig. 82, 3 (2002) 2.

[3] R. Spotorno, A. Busso, J. Pochettino, G. Figueredo, F. Benítez, Av. Energ. Renov. Medio Ambiente 15 (2011) 03.25.

[4] M. Clausse, K. Alam, F. Meunier, Sol. Energy 82, 10 (2008) 885.

[5] E. Mari, Los materiales cerámicos, Alsina, Buenos Aires (1998).

[6] SEGEMAR, "Memoria 2014", Buenos Aires (2014).

[7] L. Castillo, M. Antoni, A. Alujas Díaz, K. Scrivener, J. Martirena Hernández, Rev. Ing. Constr. 26, 1 (2011) 25.

[8] W.K. Mekhamer, Arabian J. Chem. 9 (2016) S264.

[9] L. Lian, L. Guo, A. Wang, Desalination 249, 2 (2009) 797.

[10] S. Zuo, F. Liu, R. Zhou, C. Qi, Catal. Commun. 22 (2012) 1.

[11] G. Bulut, M. Chimeddorj, F. Esenli, M. S. Çelik, Appl. Clay Sci. 46, 2 (2009) 141.

[12] A. Neaman, M. Pelletier, F. Villieras, Appl. Clay Sci. 22, 4 (2003) 153.

[13] G.D. Cancela, F.J. Huertas, E.R. Taboada, F. SánchezRasero, A.H. Laguna, J. Colloid Interface Sci. 185, 2 (1997) 343.

[14] G. Brown, G.W. Brindley, Crystal structures of clay minerals and their $X$-ray identification, Mineral. Soc., London (1980).

[15] D. De Ligny, E. Guillaud, H. Gailhanou, P. Blanc, Procedia Earth Planet. Sci. 7 (2013) 203.

[16] C.S. Tretiak, N.B. Abdallah, Sol. Energy 83, 10 (2009) 1861.

[17] J. Rouquerol, F. Rouquerol, P. Llewellyn, G. Maurin,
K. Sing, Adsorption by powders and porous solids, Elsevier, London (2013).

[18] AENOR, "Calidad del suelo: determinación de nitrógeno total, método modificado Kjedahl”, España (2001).

[19] AENOR, "Prestaciones higrotérmicas de los productos y materiales para edificación: determinación de las propiedades de sorción higroscópica", España (2015).

[20] Y.S. Ho, J. Hazard. Mater. 136, 3 (2006) 681.

[21] S. Brunauer, P.H. Emmett, E. Teller, J. Am. Chem. Soc. 60 (1938) 309.

[22] D.M. Moore, R.C. Reynolds, X-ray diffraction and the identification and analysis of clays minerals, Oxford, USA (1997).

[23] J. Thorez, "Practical XRD analysis of clay minerals workshop", Un. Nac. Colombia, Bogotá (2003).

[24] S. Gammoudi, N. Frini-Srasra, E. Srasra, Appl. Clay Sci. 69 (2012) 99.

[25] J. Madejová, Vib. Spectrosc. 31 (2003) 1.

[26] V.C. Farmer, Infrared spectra of minerals, Mineral. Soc., London (1974).

[27] D.T.B. Tennakoon, J.M. Thomas, W. Jones, T.A. Carpenter, S. Ramdas, J. Chem. Soc., Faraday Trans. 82, 2 (1986) 545.

[28] M. Bravo, N. Ale, D. Rivera, J. Huamán, D. Delmás, M. Rodríguez, M. Polo, M. Bautista, Rev. Peru. Quím. Ing. Quím. 12, 2 (2009) 5 .

[29] R. C. Mackenzie, The differential thermal investigation of clays, Mineral. Soc., London (1957).

[30] C. Avelino, F. Vicente, Quim. Nova 22, 5 (1999) 693.

[31] J. Rouquerol, F. Rouquerol, P. Llewellyn, G. Maurin, K.S. Sing, Adsorption by powders and porous solids: principles, methodology and applications, Oxford, USA (2013).

[32] S. Kaufhold, R. Dohrmann, Clay Miner. 45, 4 (2010) 441.

[33] M.L. Rueda, C. Volzone, S.Y. Martínez, Inf. Tecnol. 21, 4 (2010) 75.

[34] I. Dananaj, J. Frankovská, I. Janotka, Appl. Clay Sci. 28, 1 (2005) 223.

[35] H.H. Van Olphen, An introduction to clay colloid chemistry: for clay technologists, geologists, and soil scientists, John Wiley Sons, New York (1977).

[36] C. He, E. Makovicky, B. Osbæck, Appl. Clay Sci. 10, 5 (1996) 351.

[37] D.M. MacEwan, M.J. Wilson, in: Crystal structures of clay minerals and their X-ray identification, 5 (1980) 197.

[38] G. Sposito, Soil Sci. 115, 4 (1973) 315.

[39] C. Volzone, J. Ortiga, Process Saf. Environ. Prot. 82, B2 (2004) 170.

[40] J. Bujdák, Appl. Clay Sci. 34, 1 (2006) 58.

[41] E. Ferrage, B. Lanson, B. Sakharov, V. Drits, Am. Mineral . 90, 8-9 (2005) 1358.

[42] P. Vieillard, P. Blanc, C. Fialips, H. Gailhanou, S. Gaboreau, Geochim. Cosmochim. Acta 75, 19 (2011) 5664.

[43] C.T. Johnston, Clay Miner. Soc. 8 (1996) 1.

[44] Hypercube, Hyperchem Release 7.5 for windows, USA (2007).

(Rec. 17/02/2018, Rev. 14/04/2018, Ac. 21/04/2018) 